\title{
How institutional voids influence Brazilian foreign direct investment in Angola
}

\author{
Renato Souto Virches ${ }^{1 \mathrm{~A}}$, Fernanda Ribeiro Cahen ${ }^{\mathrm{B}}$ \\ ${ }^{A, B}$ Centro Universitário $\mathrm{FEI}, \mathrm{FEI} / \mathrm{SP}$, Brazil
}

ARTICLE DETAILS
Article history:
Received 8 March 2016
Accepted 4 April 2017
Available online in 30 April 2017
Double Blind Review System
Scientific Editor
Ilan Avrichir

\section{Keywords:}

Brazilian FDI

Africa

Multinationals from emerging markets

Institutional voids.

\begin{abstract}
How do institutional voids influence emerging market multinationals (EMNEs) foreign direct investment (FDI) in developing countries? In this article we respond to this question based on a case study approach by examining Brazilian FDI in Angola as our analytical setting. We focus on the host country's institutions and its institutional voids as essential factors that attract the FDI of EMNES to developing countries. The research indicates that Brazilian companies fill in much of these voids within the market intermediaries, often creating a point of competitive advantage, and also creating advantages in relation to FDI from other economies that invest in Angola. We complement recent research on the influence of the host country's institutions on the behavior of FDI in developing countries, explaining how some EMNEs are able to use the institutional voids of developing countries as market opportunities. Our findings provide also implications for EMNEs managers from other emerging markets by providing a better understanding of how Brazilian multinationals expand their business in less developed countries, handle institutional voids and manage relationships with local and foreign institutions in the host country.
\end{abstract}

(C) 2017 Internext | ESPM. All rights reserved.

\section{Introduction}

Brazilian foreign direct investment (FDI) has increased significantly in the last fifteen years, particularly in regard to direct investments made in other emerging countries. Between 2009 and 2010, FDI from Latin America increased by $67 \%$, corresponding to US\$ 76 billion, with Brazil accounting for US\$ 11.5 billion of the total in 2010 (UNCTAD, 2011). The African continent has increasingly attracted new investments due to the growth of its markets, the large availability of natural resources, and the demand for infrastructure projects. According to the World Investment Report (UNCTAD, 2011), between 2000 and 2009, Africa showed an increase in its global share of FDI from $0.8 \%$ to $5.1 \%$, and specifically in relation to $\mathrm{FDI}$ received from emerging countries, Africa's share reached $11.8 \%$ in 2009 and $9.6 \%$ in 2010.

\footnotetext{
${ }^{1}$ Author's contact: Email: rsvirches@uol.com.br

In African countries, Brazil, among other emerging nations, has realized an opportunity to conquer new markets, to acquire financial returns, and to benefit from the significant natural resources for their operations (Iglesias \& Costa, 2011). With this background, some Brazilian companies have been increasing their investments in these countries, particularly in countries that speak Portuguese, despite the existence of restrictive factors such as unstable political and regulatory environments, shortages of skilled labor, a lack of basic infrastructure in regards to sanitation and energy, and other limitations on the use of telecommunications and the internet. These deficiencies are characterized as "institutional voids". Institutional voids refer to the lack of mechanisms that allow the coming together of buyers and sellers of products, ideas and capital, among other assets that may be offered and consumed, in a market minimally structured by rules and laws that provide 
the necessary security to their operation (Khanna \& Palepu, 2010). These institutional voids are present in almost all market relations within emerging countries (Khanna \& Palepu, 2010).

The institutions vary according to the country (North, 1990). The host country becomes relevant not only in relation to how its institutional environment shapes the behavior of their hosted multinationals, but also how the presence of multinational companies can shape the institutional environment of the host country over time (Kwok \& Tadesse, 2006). In this study we focus on an analysis of how the institutional environment of the host country shapes certain behaviors of the multinationals that invest there. Understanding how the institutions of the host country influence FDI of companies can help us understand why some multinationals from emerging countries are more likely to succeed in unstable institutional environments (Khanna \& Palepu, 2010) This nuance of "South-South" investments, such as the role of the company's home government and that of the host country in relation to FDI (Kaplinsky \& Morris, 2009) and the filling of institutional voids, is not analyzed by the traditional theories of internationalization (Johanson \& Vahlne, 1977; Dunning, 2001). These are concentrated on private companies deriving from developed countries moving towards more stable markets, and therefore having lower risk. (Guillén \& Garcia-Canal, 2009).

The few studies about FDI in Africa reveal that reasonably stable institutions, along with a reliable legal system, are pre-conditions that stimulate the arrival of multinational companies. This is indicated by the work of Ramasamy, Yeung and Laforet (2012), when comparing the entry of foreign manufacturing companies into nineteen sub-Saharan countries. The results of the study indicate that countries with the most institutional stability manage to stimulate the links between local partners and foreign companies that guide these market relations. On the other hand, Ramasamy et al. (2012) saw, in the study of Chinese $\mathrm{FDI}$, that companies controlled by the state are attracted to countries with large sources of natural resources and risky political environments, such as African countries. Companies with this profile can manage to fill-in the local institutional voids more easily, since they have bigger budgets and resources that enable them to take more risks. Therefore, although some institutional stability is necessary to attract FDI, the institutional voids, which in return creates large risk, attracts FDI from states or private companies connected to the interests of their home governments.

Until now these relationships have been little explored in the literature on multinationals of emerging countries in regards to the FDI of Brazilian companies in Africa. The scarce literature on FDI in Africa has been largely dedicated to the analysis of Chinese investment in the region (Balasubramanyam, 2015; Ramasamy et al, 2012; Kaplinsky \& Morris, 2009) or Indian investments (Adeleye, White, Ibeh, \& Kinoti, 2015; Chakrabarti \& Ghosh, 2014).

In this context, this study answers the question: How do the institutional voids influence Brazilian foreign direct investment in Angola? We focus on the host country's institutions and its institutional voids as essential factors that attract the FDI of emerging market MNES to developing countries (Khanna \& Palepu, 1997). We then examine Brazilian FDI in Angola as our descriptive and analytical setting. We aim to enhance our understanding of the unique aspects of emerging market MNEs going to developing countries, and to comprehend how these firms are sometimes able to use the institutional voids of these countries as market opportunities.

By conducting this study, we attempt to make two contributions. Firstly, we bring empirical evidence of FDI by emerging market multinationals in Africa. Such an examination complements recent research on the influence of the host country's institutions on the behavior of FDI in developing countries (Ramamurti, 2012; Khanna \& Palepu, 2010; Peng, Wang, \& Jiang, 2008). In this sense, we bring new elements to institutional theory studies explaining Brazilian companies doing $\mathrm{FDI}$ in different institutional contexts in the African continent. We extend current research regarding impacts of host institutions on firm strategic choices (Chacar, Newburry, \& Vissa, 2010; Peng et al., 2002) and on internationalization of emerging market multinationals (Ramasamy et al., 2012) by discussing that the host-country institutions may directly influence the delivery of product and services. Secondly, this study also complements research on FDI in Africa, which has been focusing repetitively in investments from China and India and hence assumes away differences regarding the origin of the firms (Adeleye et al., 2015; Chakrabarti \& Ghosh, 2014).

In practical terms, understanding the effects of host-country institutions on FDI may bring answers of 
which type of firms are more likely to succeed making investments in less developed countries. Examining host-country institutions can also bring answers if companies from diverse institutional environments have different motivations to make investments in less developed countries.

In the next section we will present the main theories on foreign direct investment in emerging markets, and their relation to the discussion on institutional voids. In section 3 the research methodology, followed by the results. Finally, there are the main conclusions and new ideas for future studies in regards to the theme.

\section{Literature review}

2.1 Foreign direct investments in emerging markets and the institutional voids

Emerging countries are the ones that are in the process of adopting structural reforms and whose economy is still in the process of growth, albeit below those of so-called developed countries (World Bank, 2012). The countries referred to collectively as the BRICS nations (Brazil, Russia, India, China and South Africa) can be considered some of the most promising emerging economies (Khanna \& Palepu, 2010). According to UNCTAD (2011), the emerging markets were responsible for about $25 \%$ of the whole global FDI in 2010. For the purposes of comparison, the percentage in 2011 was 6\%. Foreign direct investments are those performed outside the home country and can be through the implantation of subsidiaries (greenfield), the merger or acquisition of other companies, or even through the creation of new organizations which result from a partnership with other companies (joint ventures) (PENG et al., 2008). Product export activities are not considered FDI.

The theories about internationalization of companies and the majority of their studies have traditionally been focused on understanding the flow of investment termed "North-South", meaning those from developed countries to emerging countries (Dunning, 2001), or "North-North" FDI, which derive from developed economies and go to other economies which are also developed. Aykut and Goldstein (2007), Ramamurti (2012), and Khanna and Palepu (2010) are some of the authors who have dedicated themselves to the study of FDI termed "South-South", that is the FDI of a company from an emerging country into another emerging country.
According to these authors, companies of the largest emerging economies would have the following among their characteristics: the abundant use made of natural resources along with the utilization of a cheaper workforce, the exhibiting of few technologic skills linked with a low level of managerial training, and the familiarization to operating in an institutional environment that is more turbulent and unstable.

Institutions are entities created to structure and regulate political, economic, and social interactions (North, 1990). The "rules of the game" are those made up by formal institutions, including laws and regulations, and informal institutions, made up of values and social norms. Normally, the government creates the legislation to regulate the economy and the definitions that govern the regulatory and competitive environment in which business is conducted, whilst the private sector makes efforts to influence governmental policies. Thus these institutions, designed for a particular country, can encourage or discourage the entrance of foreign companies, as well as encourage or discourage the international expansion of national companies (North, 1990).

On the other hand, institutional voids are defined as the result of a congruence of factors, among which are the absence of clear regulatory frameworks, a lack of legal protection, inefficient laws, an unstable political environment, and excessive interference from governments (Luo \& Tung, 2007). The idea that institutional voids are related to underdeveloped markets, poor infrastructure, and a lack of effective application of rules and regulations (Khanna \& Palepu, 2010) has played a key role in the strategic choices of companies and their investments in emerging markets.

Authors who have systematically studied FDI from emerging countries (Khanna \& Palepu, 2010) point out that the institutional voids, in destination countries, can also represent investment opportunities, such as rapid market penetration due to low entry barriers, less regulation and bureaucratic processes, and more attractive financial returns. Another aspect that seems to favor multinational companies from emerging countries seeking internationalization in other emerging markets would be the experience acquired in its home market. This would contribute to the adaptation of strategies and the ability of the company to adapt to existing institutional frameworks in emerging markets. 
According to North (1990), although it is the prerogative of governments to create institutions and rules, in the case of emerging markets, many private groups take on this role by regulating the business environment in as simple a form as necessary and invariably affecting social and economic factors these countries. Yet in regards to the filling of institutional voids, such actions can be characterized as opportunities for companies, domestic or foreign, that want to create new business based on filling these gaps. Several examples that deal with the entrance of companies into emerging markets show that the most successful operations were those where the companies could adapt to the existing institutional voids within the target markets, often filling those voids with complementary operations to its main products or services (Khanna \& Palepu, 2010).

\subsection{Market dimensions and the institutional voids}

Emerging markets rarely have exactly the same characteristics in regards to the nature and extent of the institutional voids. According to Khanna and Palepu (2010), and taking into account the characteristics of the macro context, the development of any business strategy always derives from three fundamental markets; product, labor and capital. Moreover, when it comes to emerging markets, institutional voids are normally present in at least one of these, and usually in all three market types.

\section{a) The Product Markets}

In general, the mechanisms in regards to consumer product markets rely on light and heavy infrastructure (Khanna \& Palepu, 2010). Light infrastructure includes advertising agencies and other means of communication that facilitate corporate communications, such as and among others, market research firms or agencies of credit risk classification. So-called heavy infrastructure includes the pre-existing ports, roads, and bridges that provide an adequate logistical flow for the transportation of goods and products from suppliers to retailers, and consequently, to end-users. Also included in heavy infrastructure are the existing federal, state, and local public institutions that establish different laws and regulations, as well as the respective courts that make sure such regulations are effectively enforced.
Yet in product markets there are several other points to consider in developing more assertive strategies, for example, the commitment given by input manufacturers to, among others things, the non-sharing of data and confidential information by credit card companies, no false advertising about the real benefits of certain products, and the possibility of consumers taking court action if they feel misled with regard to the purchase of a product or service.

The above factors to a greater or lesser extent prevail in developed economies, but are usually significantly lacking in emerging economies. Therefore, in the case of product markets in general, there is a need to assess the existence of institutions that further the security needed for the introduction, development and marketing of products, particularly in relation to the existence of clear rules for the regulation of competition (Chacar et al., 2010).

\section{b) The Capital Markets}

In the capital market of a country we can cite the direct agents and intermediaries. The direct agents are commercial banks, insurance companies, the central bank, and the stock exchanges, these being important mechanisms for trading offering liquidity to investors in allowing free trading of their assets. Intermediaries consist of rating agencies, financial analysts, and the trade press (North, 1990). In general, capital markets and their intermediaries have stricter regulations in developed markets. The fact is that by reducing the risks for new investors, the different intermediaries of the capital markets allow competitive conditions and more equitable investment, regardless of size or business sector.

Established accounting standards and the existence of independent auditors also contribute to the development and upkeep of more consistent financial reports, which allow, ultimately, for greater credibility of institutions and other economic agents in the market. Economies that allow easier access to lines of credit and capital, that are less bureaucratic and at lower cost provide better conditions for the growth of their economies and their markets, allow investors to find the best-case scenarios for competition and the development of new business (Khanna \& Palepu, 2010).

c) The Labor Markets 
In regards to labor markets, according to Khanna and Palepu (2010), the analysis would involve: the existence of formal educational institutions in the country, the analysis of the degree of education and its suitability to the local demand, the presence of recruiting and headhunting agencies, the maturity and guarantees in regards to employment contracts, and the existence of trade unions and government programs, such as unemployment insurance, among others.

Markets with a solid working structure, endowed with strong regulatory institutions overseeing relations between employers and employees, would avoid possible problems related to the hiring and management of the workforce in that country. This therefore forms an important basis for growth in international companies, who can rely on efficient and clear laws regarding the mediation of labor relations (Chacar et al., 2010).

The availability of properly trained human capital is a key factor for growth and development of an economy, as new investments involving projects, products and business are invariably developed from human involvement, albeit directly or indirectly (Chacar et al., 2010). However, emerging countries present a largely unskilled workforce and questionable labor relations (Luo \& Tung, 2007). This affects the behavior of companies operating in the country, which usually set up manpower intensive manufacturing operations to take advantage of the low cost of local labor (Khanna \& Palepu, 2010).

\section{d) The Macro Context}

"Politics, history and culture affect the development, form and function of the institutions, and the existence and persistence of institutional voids" (Khanna \& Palepu, 2010, p. 35). Thus, the more general and intrinsic factors of the country may lead to deficiencies in creating and implementing regulatory institutions in the market. Factors such as, the size and capacity of independence of the local media, the existence of non-governmental organizations and environmental groups, the ease or otherwise with which foreign investment enters into the country, and the time taken to set up new businesses.

As an example of a situation where the macro context directly relates to the establishment of an institution, one can cite the fact that institutions in the capital market are directly affected by their governments, who are not culturally adept at providing and disclosing information about their government accounts.

To sum up, based on previous literature, we will focus on the influences of FDI on the product market, the capital market, and the institutions of the labor market (Khanna \& Palepu, 1997). These institutional dimensions are key factors in discerning the emergence and success of companies (Khanna \& Palepu, 2010; Luo \& Tung, 2007). We therefore start from the literature on FDI in emerging countries (Aykut \& Goldstein, 2007; Ramamurti, 2012, Khanna \& Palepu, 2010; Luo \& Tung, 2007) that claim the significant influence of developing countries' national institutions in FDI decisions. The underdeveloped institutional environments in these countries often attract companies from emerging countries, which at some level have learnt to deal with unstable institutional environments in their home country (Ramasamy et al., 2012).

\section{Methodology}

\subsection{The Nature and Justification of the Research}

The nature of this research is qualitative and exploratory, and following Eisenhardt (1989) in our decision to adopt a case study approach to analyze the FDI of Brazilian companies in Angola. This methodological choice is appropriate given the complexity of understanding the specific institutional features of our research setting, Angola, as an FDI recipient. The country has its own peculiarities, given, among other limiting factors, its deficiencies in infrastructure, overexposure to risk, lack of clear regulatory frameworks, and economic and political instability (Dupasquier \& Osakwe, 2006; Asiedu, 2002). A single case study is suitable as a first step (Ghauri, 2004) in testing and building a theoretical model to explain the FDI logic of EMNEs investing in less developed countries.

The methodological choice of this project was made given the four principle factors:

1) The literature on FDI in Africa is scarce in the international business area, and the few studies that exist focus on Chinese FDI in the continent. Besides that, existing Brazilian studies on FDI in Africa analyze FDI in the continent as a whole and do not analyze the particularities of the countries. 
2) The official data from Angola regarding FDI is inaccurate and / or contradictory.

3) In most FDI activities there are unclear relations with governments (Brazil-Angola).

4) There is evidence of corruption in some FDI activities.

In this context there is a clear difficulty in obtaining primary data from companies in relation to their investment in Angola. This study was based mainly on secondary data sources and a survey of exploratory primary data through informal interviews held during visits to the country by the researcher.

\subsection{Data Collection}

In accordance with Berg and Lune (2008) quantitative and qualitative secondary data was used in this research. The secondary quantitative data used was from four main sources: 1) WIR (World Investment Report) prepared by the UNCTAD (United Nations Conference on Trade and Development) that publishes specific sections on FDI in Africa; 2) Data from APEX BRAZIL, the Brazilian governmental agency that monitors and supports the internationalization activities of Brazilian companies; 3) Data from the Brazilian Central Bank, which has published the census of Brazilian FDI abroad since 2002; and 4) World Bank data on the economic and institutional environment in Angola.

The secondary qualitative data was obtained by means of a manually collecting data in regards to the different operations of Brazilian companies in Angola, from their websites and annual reports, and also from journalistic sources in the national and international media. Five exploratory informal discussions (informal interviews) were collected by opportunity with business people, three executives involved in the operations of Brazilian companies and two government officials in Angola, during three visits by the researcher to the country in2014. In these discussions the researcher asked questions about the entry and the operations of Brazilian companies in Angola. Unstructured interviews as a primary data collection is common in exploratory research. These informal interviews are in accordance with exploratory research techniques in qualitative exploratory research (Creswell, 2012). Unstructured interview is an informal, conversational interview, based on unplanned set of questions that emerge during the conversation. The researcher took notes during these conversations, but no structure questionnaire was used. This study did not draw on other primary sources, for example, by conducting structured or semi-structured interviews with Brazilian companies that have FDI in Angola. At the time that this study was being conducted, intense investigations were being carried out into the major Brazilian contractors for an alleged corruption scheme involving contracts with Petrobras. These are the same companies mentioned in this current study dealing with Brazilian FDI in Angola, making restricted access to primary information more systematized.

\subsection{Data Analysis}

Our results were developed following Eisenhardt (1989). Four steps were followed keeping up with standard procedures of data analysis in case-study research: Firstly, all the secondary data on the companies were analysed individually to allow the researchers to identify the amount of FDI the company have done in different countries in Africa, and then separate all the FDI the companies have done in Angola. Secondly, to organize our data one key step was the within-case analysis to understand how all the companies have entered the Angola market, how they have evolved after the firm's entry in the country. In this phase we identified chronological details, investments circumstances, motivations for investing in Angola. As we used secondary data we systematically collected information on the companies. Thirdly, a cross-case analysis was carried out in order to identify patterns of all the companies we had identified. Finally, we systematized the data collected on the institutional environment of Angola. This was done by selecting categories and then looking for similarities and differences across the companies we had identified in step two (Eisenhardt, 1989). The categories are the components of Khanna and Palepu (2010), which establishes product markets, capital, and labor as the three main situational analyses to be considered in analyzing institutional voids. The authors also emphasize that the macro institutional environment is relevant to understand the influence of institutional voids on FDI and we decided to include this category in our analyses.

\section{Results}

\subsection{The General Overview of FDI in Angola}


From 2002 to 2011, Angola had an average annual GDP growth of around $12 \%$, driven primarily by extractive activities and on the basis of the FDI of foreign firms (UNCTAD, 2013a). This is an economy primarily composed of the mineral extraction industry (70.9\%), service industry (20.5\%) and agricultural industry (8.6\%), with shipping as the primary means of access for foreign trade (UNCTAD, 2013b). In regards to the flow of IFDI (Inward foreign direct investment) into Angola, there was a rapid growth in the rate of investment in the country between 1990 and 2009, with a downward trend thereafter, given the lowering of the country's investment grade (See Figure 1).
Weisbrod,2012). Russian FDI in Africa is around US\$ 5 billion (UNCTAD, 2013a). In Angola in particular, Russians have an important share in investments made for the capture of high value minerals such as diamonds, through the Russian company ALROSA. Besides that, Rusal, the largest aluminum producer in the world, has operations in Angola, Guinea, Nigeria and South Africa. Russian banks are also moving into Africa. The Vneshtorgbank, for example, opened the first foreign majority-owned bank in Angola, and then moved into Namibia and Côte d'Ivoire (UNCTAD, 2013a). The stock of South African FDI on the continent is US\$ 18 billion. Most of its FDI stock in Africa is carried out in Mauritius. Several South

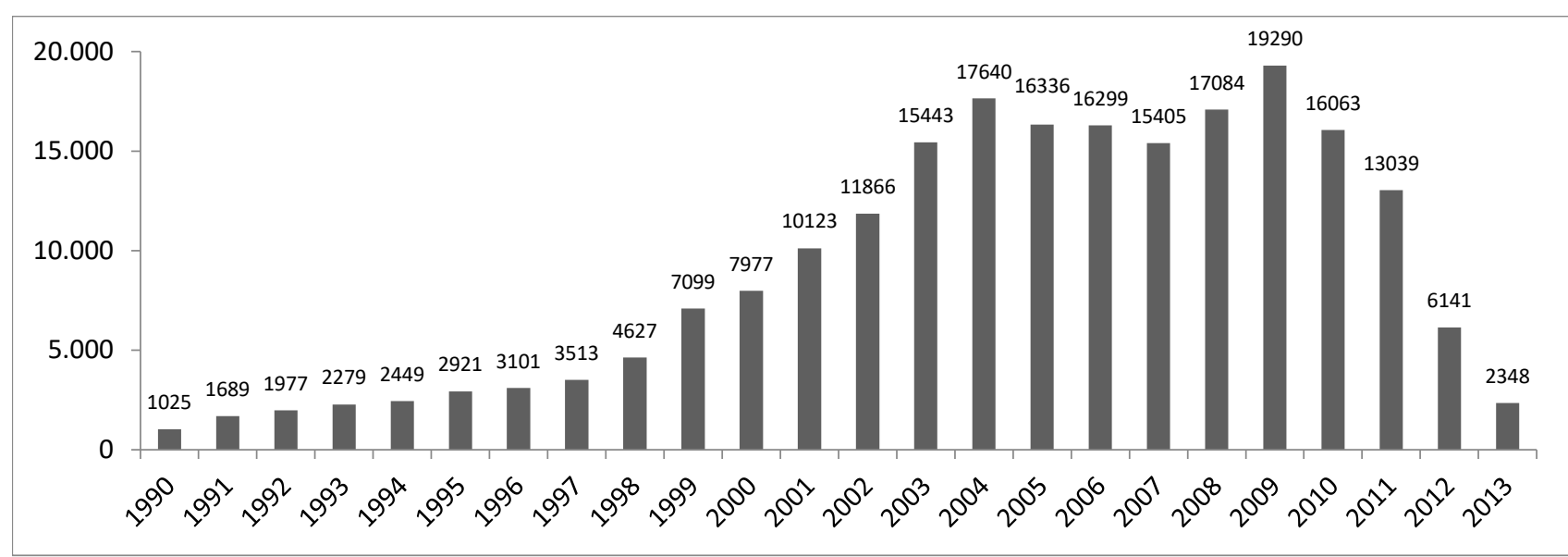

Fig. 1

Inward FDI Stock in Angola in US\$ millions (1990-2013)

Source: UNCTAD (2013a).

Although most of the foreign direct investment in Africa is still coming from North American and European companies, the BRICS nations have been major investors in the continent in recent years (Broadman, 2011). Their share in the overall FDI in African countries reached $25 \%$ in 2010. Malaysia (stock of US\$ 19 billion), South Africa (stock of US\$ 18 billion), China (stock of US\$ 16 billion), India (stock of US \$14 billion) and Brazil (stock of US \$11 billion) are the largest sources of FDI in developing countries in Africa (UNCTAD, 2013a).

In the context of the BRICS nations, China has the second largest FDI in Africa, with around $\$ 16$ billion of investment (UNCTAD, 2013a). In the case of Angola, Chinese FDI appears to be lower when compared to other African countries. Over the period between 2003-2009, Angola received a lot of aid and loans from the Chinese government, but only a small amount of Chinese FDI (receiving less than Kenya or Ghana over the same period, according to Whalley \&

African companies have investments in the mining sector in Angola, but there are no precise figures for these activities.

\subsection{The evolution and stages of Brazilian FDI in Angola}

Further research into the participation and characteristics of Brazilian FDI in Angola revealed three distinct stages of its evolution over time.

\section{Phase 1: 1979-1995}

The arrival of Petrobras in Angola in 1979, and the continuity of their projects throughout the 80 s and early 90 s, can be seen as a first phase. This period was a preliminary stage of getting to understand operations in Angola, with the goal being the search for alternative sources of energy for Brazil. Soon after, in 1984, Odebrecht was the first company in the Brazilian construction sector to act on interest in 
Angola, due to the many opportunities brought about by infrastructure projects in that country.

\section{Phase 2: 1995-2005}

The second phase culminates with the beginning of President Lula's administration (2003-2010), an important driver and promoter of Brazilian ties with Angola, as part of Brazil's strategy of increasing South-South relations. The actions of this administration contributed to the expansion of Brazilian FDI in the country and the beginning of the diversification of established businesses. They initiated the advancement of the leading companies already operating in the oil, gas, and construction sectors, along with the development of new projects and the arrival of new constructors such as Andrade Gutierrez, Camargo Corrêa, Queiroz Galvão and Engevix, due to the great need for infrastructure projects driven by the demands of extractive Brazilian companies, those principally being Petrobras and Vale. During this period there was both an increase in the Brazilian participation in joint ventures, and also in "greenfield" type investments.

\section{Phase 3: Post-2005}

After 2005, there was greater participation and diversification of Brazilian businesses in Angola. This third phase is characterized by Brazil's entry into new sectors extending past the original "core business" of some companies, as in the case of Odebrecht's expansion into new projects involving Petrobras and Vale. Odebrecht, in particular, has very diversified operations involving sanitation and waste disposal, agricultural production, operations related to oil extraction and mining, as well as acting in supermarket management, among others. This most recent period is also characterized by the growth of the Angolan market, spawning an emerging middle class that demands new products and services, and the attracting of new investments, especially in new service sectors, education, information technology and agribusiness (World Bank \& IPEA, 2011). Extending this phase until the present day, there has continued to be a slight improvement in the economic and social indicators of Angola. However, some key existing latent institutional voids still remain, such as the absence of clear regulatory environments, the lack of credit and qualified market information, plus significant governmental influence over decisions on and approval of projects, the lack of a qualified local workforce, and the strong suspicion of corruption. These issues are regarded as a cultural factor that is still quite rooted in Angola (World Bank \& IPEA, 2011).

More recently, in 2010, the Brazilian government, with the creation of APEX-Brazil and the establishment of a Business Centre in Luanda, has further facilitated the setting up of Brazilian companies in Africa (Iglesias \& Costa, 2011; World Bank \& IPEA, 2011). However, the closer ties between Brazil and Africa was not only due to economic interests, but also largely due to the political interests during the time of Lula's administration, which also sought the support of Angola and other African countries for their wish for greater participation and representation of Brazil in global organizations and economic forums (Vilas-Bôas, 2011).

4.3 The influence of institutional voids on the Brazilian FDI in Angola

The influence of institutional voids on Brazilian FDI in Angola was analyzed accordance with the theory of Khanna and Palepu (2010). This model establishes product markets, capital, and labor as the three main situational analyses to be considered in any given economy.

\subsubsection{The Product Market}

Regarding the product market in Angola there is a serious lack of intellectual property protection laws and other factors relating to manufacturing warranty, often with the direct or indirect participation of the government, since the domestic industry in general is very diverse. Many consumer products are imported, from food to other value added products, such as electronics. Public serves, such as education, healthcare, transport and security are generally poor (Garcia, Kato, \& Fontes, 2014), directly affecting trade and market transactions. It could be said that much of the current situation is connected in some way to the civil war that lasted over twenty years. On the streets of the capital Luanda you can see open sewers, power outages almost daily, and a chaotic transport system comprising an insufficient network to service the population.

Along with these problems, there is also the fact that there are no satisfactory laws protecting free trade with the participation of market regulatory institutions monitoring and adjudicating on possible 
excesses and unethical actions carried out by local or foreign companies. However, although the Angolan economy is still very dependent on foreign goods, and sustains itself mainly from revenues from the exportation of its oil and mineral resources, it has shown a significant growth of its domestic markets in recent decades, especially with the increase of the country's middle class that has stimulated the demand for new products (Garcia, Kato, \& Fontes, 2014).

Thus, many Brazilian companies, not just Petrobras, Vale, Odebrecht, Camargo Corrêa, and Queiroz Galvão, but also companies from other sectors and services, have established themselves in Angola as a way of taking advantage of the growth opportunities within this emerging demand. Examples are: O Boticário, Casa do Pão de Queijo, Wizard, Fisk, among others, which have taken advantage of the increasing demand to consolidate their operations in Angola.

The survey revealed a certain skill and adaptability, on the whole, of Brazilian companies in dealing with the Angolan product market. As examples, the initiative to build roads, carried out by the main contractors in the country, driven by the need to distribute production related to the extraction of oil and other minerals. Furthermore the establishing of construction companies such as Andrade Gutierrez, Queiroz Galvão, and Camargo Correia, among others, attracted by the opportunities generated by the arrival and establishment of Petrobras and Vale in the region.

\subsubsection{The Capital Market}

The capital market in Angola proves to be very focused on banks of Portuguese origin, although Angolan banks have expanded their bases and interests in recent years. The lack of both banking regulation and development of banking services among the population remain an issue. Angola is still a harsh market for business from the point of view of the supply and availability of credit (Garcia, Kato, \& Fontes, 2014; Iglesias \& Costa, 2011; Vilas-Bôas, 2011).

Despite the existence of the BNA (National Bank of Angola), a kind of central bank of the country, and the presence of a little more than a dozen banks already established in the region, there is still a great lack of credit in the country. This may be due to the high risk associated with loans and financing operations, due to the lack of efficient guarantee mechanisms to enable the necessary ballast for a bigger and better policy provision of capital by financial agents (Garcia, Kato, \& Fontes, 2014; Iglesias \& Costa, 2011; Vilas-Bôas, 2011).

This scenario of a lack of credit and much economic instability, caused largely by the void of institutions and clear regulations in respect to the use of the national currency, has led to the need for Brazilian companies to depend on credit coming from Brazil, especially from BNDES (National Bank for Economic and Social Development) and other public banks, such as Banco do Brasil and Caixa Econômica Federal. In some situations there is also the involvement of local financing granted by Brazilian banks, as in the case of Bradesco.

As a way to fill the institutional void in regards to the need and supply of credit, Brazilian companies have often sought such funding from Brazilian banks, although in many projects, the Angolan government itself also acts with a certain direct involvement, especially in projects related to construction for public services and other initiatives of governmental interest. Therefore, what stands out is the country's infrastructure construction such as roads, airports, hospitals, schools and other public service projects. In projects related to the principle riches of the country, such as oil and mineral resources, what is always noted is the involvement of the Angolan government, through the participation of state-owned Angolan companies in these businesses.

It is important to mention this aspect of the filling of the institutional void, as done by some Brazilian multinationals, due to the lack of sufficient credit and credit regulation institutions to provide the necessary security for financial transactions. This filling, as described by the theory of Khanna and Palepu (2010), is characterized as an interesting opportunity for Brazilian investment in Angola. In this sense, the availability of Brazilian capital as a driver of many Brazilian projects in Angola not only facilitates the creation and signing of many contracts between Brazilian companies and the government of Angola, but also enables Brazilian companies greater penetration into these markets, and to better exploit existing opportunities in the country. Given the need for quick growth within the country, the Angolan government has offered generally good financial returns in relation to projects carried out by foreign enterprises, Brazilian enterprises being among then, 
especially in the markets of petroleum and mineral extraction. Indeed, this seems to be one of the main reasons for the appeal to Brazilian foreign investment, despite the existing risks due to the institutional voids present in the country. The influence of the Angolan government seems to favor the influx of Brazilian companies from relevant sectors that can establish a good relationship with local government, and take advantage of the ties that were created in the past by the Brazilian government, that is, Lula's administration from 2003 onwards (Garcia, Kato, \& Fontes, 2014; Iglesias \& Costa, 2011; Vilas-Bôas, 2011).

\subsubsection{The Labor Market}

In regards to the labor market it is important to note that the absence of intermediary institutions dedicated to the hiring, training, and improvement of human resources necessary for the activities of Brazilian companies in Angola, becomes a major obstacle in the development of such operations.

The findings of this study is that one way of solving this problem has been the filling of these voids in the form of the own initiatives of Brazilian companies. Brazilian companies tend to use local labor for the development of their projects and enterprises, whilst applying management models more aligned with human rights. These practices are the result of the inheritance of the working model already adopted in Brazil, established from labor advances throughout history (Vilas-Bôas, 2011; BBC Brasil, 2013).

When there is a need to increase the hiring of local labor, companies, especially in construction and mining, have invested in projects to train people, promoting courses and training in partnership with civil society institutions and local governments. An example is the "Believe" program in Angola, created by the Odebrecht construction company in partnership with SENAI (Serviço Nacional de Aprendizagem Industrial), in order to replicate the pattern of training as carried out on Brazilian soil (Iglesias \& Costa, 2011).

Another important aspect concerns the experience of many of major Brazilian companies, mainly in the construction, oil and mining sectors, like companies such as Norberto Odebrecht, Andrade Gutierrez, Queiroz Galvão and Camargo Correa, which are all construction companies, SENAI as an important provider of local development and skills, and EMBRAPA, considered a reference in the generation of knowledge and technology for agro pastoralism. The latter is perceived in Angola as an important Brazilian initiative, given the need to increase food supplies in order to supply the population in the coming years (Iglesias \& Costa, 2011).

\subsubsection{The Macro Context}

In regards to the macro context and the existence of institutional voids, the theme of "corruption" seems to be ever present in discussions about Brazilian FDI and investment activities in Angola (Garcia, Kato, \& Fontes, 2014). Although it is seen as a controversial and difficult subject to deal with, as it is most often hidden, it is a critical phenomenon in regards to the challenges faced by Brazilian FDI in African territory.

In Angola for example there is an obscure political scenario in relation to the transparency of government procurement and public service contracts as agreed upon by Brazilian companies and local government, which is a typical scenario within an institutional void. A good example of this void concerns the lack of disclosure about bidding procedures for public contracts. It is noted that political and corporate ties guide the major investment decisions in the country, and often subsidize the formulation of contracts (Garcia, Kato, \& Fontes, 2014).

The PACS report (Garcia, Kato, \& Fontes, 2014), a study that conducted several interviews with local agents in Angola and Mozambique, including with governmental, private, academic, and social leaders, and trade unions and representatives of international organizations, pointed out the high number of mentions made about corrupt processes. This perception can be exemplified by certain oral statements mentioned in some of the interviews in the study, such as:

With regard to infrastructure projects, there are many problems. The first of them is the lack of transparency in the bidding process. The second is the quality of services provided. At the request of the government itself, they [the builders] overload the budget with things that were not anticipated, and increase the budget to facilitate the payment of commissions or "fizz" (Garcia, Kato, \& Fontes, 2014, p. 25).

There is no distinction made between public and private. There is an illicit marriage between the state and the private sector here. And no one is ready to challenge that (Garcia, Kato, \& Fontes, 2014, p. 25). 


\section{Results and discussion}

This work aimed to contribute to the analysis of foreign direct investment among emerging countries, namely, a study directed at the analysis of FDI fostered among the economies of the so-called South-South axis, with important findings about the characteristics of Brazilian FDI in Angola and the challenges and opportunities in regards to the existence of institutional voids.

Regarding the question "How do institutional voids influence Brazilian foreign direct investment in Angola?" Our research brings insights to current theories of firm internationalization in two key ways. We integrate the discussions of institutional voids in developing countries and recent IB theories regarding FDI of emerging market firms in less developed. Our study describes an empirical experience of Khanna and Palepu's (2010) framework contribution on institutional voids in emerging markets by analyzing the path of Brazilian multinationals doing FDI in Angola.

The key findings of this research were:

In the case of the product market, due to the fact that there are institutional voids Brazilian FDI in Angola is, above all, represented by companies in the oil and mining areas that sought to build their own outlets for their local production. In addition, Brazilian companies often also develop their own supply chains, given the need to supply the necessary raw materials to local operations. Thus, we see the tendency to fill some of these voids by means of Brazilian investment with a view to taking advantage of these deficiencies in order to establish themselves in Angola more effectively, and to facilitate their operations within the country.

In the capital market of Angola there is a notable lack of access to credit and significant financing. This institutional void is due to the fact that the Angolan banking credit market is still growing within the country, and with modest banking rates. With the existence of this void being an important factor within the country's economy, for the purposes of Brazilian investment there is a necessity to seek credit lines to Brazilian banks, such as BNDES, Banco do Brasil, and Caixa Econômica Federal, along with a few private banks in some cases.

Regarding the labor market, the indicated important institutional void refers to the lack of skilled labor, and in the quantity necessary to conduct
Brazilian projects in Angola (Vilas-Bôas, 2011; Iglesias \& Costa, 2011; Garcia, Kato, \& Fontes, 2014). Many Brazilian companies opt for the utilization of the labor of local Angolan workers, despite the lack of skills, and provide the appropriate professional training themselves. This approach is distinct from Chinese competitors for example, which in most cases choose to bring a workforce originating from their home country.

As for the Angolan macro context, "corruption" and obscure relationships between local and Brazilian governments appear to be present in some of the activities of FDI (Garcia, Kato, \& Fontes, 2014), and FDI by Brazilian companies that know the modus operandi of local and Brazilian governments, in relation to how business is conducted in that country, appear to benefit. The Brazilian FDI undertaken in Angola is largely carried out by state-owned enterprises. This finding corroborates recent studies of the FDI behavior of Chinese companies on the African continent (Ramasamy et al., 2012) and can be generalized as the behavior of companies from emerging countries, which are for the most part state-owned enterprises, or have the involvement of their home countries (Cuervo-Cazurra, Inkpen, Musacchio, \&Ramaswamy, 2014).

Accordingly, Brazilian FDI in Angola not only takes advantage of the institutional voids in order to set up, explore, and develop in the region, but also seeks to fill some gaps, especially when it sees the institutional void as an opportunity to increase business (Khanna \& Palepu, 2010).

In addition to the specific discussion of Brazilian FDI in Angola, this study also answers the question: "Why are companies from emerging markets interested in carrying out FDI in less developed countries that also have more institutional voids than their home country?"

Firstly of all, the FDI of companies from emerging markets may have a political factor in their activities and in their geographical choices (Ramasamy et al., 2012; Cuervo-Cazurra et al., 2014). For the most part, these companies are either state-owned or have a strong relationship with their countries of origin, and can internationalize to achieve political objectives that have little to do with the stated logic of traditional theories of international business, where companies seek markets, natural resources, strategic assets and efficiency to increase profitability (Dunning, 2001). As a result, companies in emerging 
markets may show a greater risk tolerance in deciding to enter countries that are considered a gamble or underdeveloped (Ramasamy et al., 2012). Accordingly, they are more likely to make FDI through acquisitions and greenfield projects (Ramasamy et al., 2012) in countries with weak institutional environments compared to their home country, in general because their government supports the investing company by means of policies, low cost borrowed capital, or direct financial backing when it comes to state-owned enterprises. In this study we can clearly see this behavior in the investments of Petrobras and of Embrapa, and of the Brazilian contractors and extractive companies in Angola supported directly by the Brazilian government or by the financing of BNDES.

Overall, these findings suggest that greater institutional voids lead to greater efforts of emerging markets firms regarding their home governments and political negotiations with the host country to accomplish FDI. We further argued that this behavior is closely aligned with emerging market firms location choices, which notes that if these firms internationalize, they tend to do so in a risk-seeking manner as they expand to other countries with similarly unstable governments and sometimes less developed countries - i.e., both politically and institutionally - and rich in natural resources (Ramasamy et al., 2012).

\subsection{Limitations and future research}

This study has two main limitations. First, it focuses only on one country; therefore it brings to light the need to conduct multiple case studies of Brazilian FDI in other African countries. This limits the generalizability of results. Future research needs to study additional emerging market firms from different countries doing FDI in Africa, and make comparisons among them for more meaningful results. An important component of future research should be use of external measures of institutions such as the Global Competitiveness Index or the Governance Indicators of the World Bank.

Secondly, this study has extensively used secondary research sources. This limitation is justified, as it cannot be expected that in-depth interviews would bring more specific information than that already disclosed in open sources, considering that many questions involve controversial issues such as corruption and hidden relations. Nevertheless, it seems appropriate to carry out in-depth interviews with others agents involved, whether they are from the governmental side or within the private sector, in order to deepen the understanding of the principle driving forces and ongoing interests and ties when considering Brazilian FDI in Angola and emerging market firms in Africa.

Finally, more research is needed exploring the political side of emerging market firms doing FDI in African countries (Ramasamy et al., 2012). In many circumstances, these companies invest in countries to achieve political objectives of their governments, sometimes corrupted political objectives, which have little to do with profitability or financial performance (Cuervo-Cazurra et al., 2014). Some Brazilian companies under corruption investigation are examples of this political influence in the decision of FDI in unstable countries.

\section{References}

- $\quad$ Adeleye, I., Ibeh, K., Kinoti, A., \& White, L. (Eds.) (2015). The Changing Dynamics of International Business in Africa (AIB Sub-Saharan Africa $\{\mathrm{SSA}\}$ Series). London: Palgrave Macmillan.

- Agência Brasileira de Promoção de Exportações e Investimentos \{ApexBrasil\} (2012). Angola - Perfil e oportunidades comerciais. Retrieved from http://www.apexbrasil.com.br/Content/imagens/d806 c1ec-c36a-4d8f-be6b-8b91fdc7f29b.pdf.

- Asiedu, E. (2002). On the determinants of foreign direct investment to developing countries: is Africa different? World Development, 3(1), 107-119.

- Aykut, D., \& Goldstein, A. (2007). Developing Country Multinationals: South-South Investment Comes of Age. In Industrial development for the 21st century: sustainable development perspectives (pp.85-116). New York: United Nations.

- Balasubramanyam, V. N. (2015). China and India's economic relations with African countries - neocolonialism eastern style? Journal of Chinese Economic and Business Studies, 3(1), 17-31.

- Banco Mundial \& Instituto de Pesquisas Econômicas Aplicadas (2011). Ponte sobre o Atlântico: Brasil e África Subsaariana - parceria Sul-Sul para o crescimento. Brasília: IPEA. Retrieved from: http://www.ipea.gov.br/portal/images/stories/PDFs/liv ros/livros/111222_livropontesobreoatlanticopor2.pdf

- BBC Brasil (2013). Brics competem para ganhar terreno na África (26 mar. 2013). Retrieved from http://www.bbc.co.uk/portuguese/noticias/2013/03/1 30326_brics_rc. 
- Berg, B; Lune, H. (2008). Unobstrotuve measures in research. In Qualitative research method for the social science. Boston: Pearson.

- Broadman, H.G. (2011). The backstory of China and India's growing investment and trade with Africa: separating the wheat from the chaff. Columbia FDI Perspectives, n. 34, February 17, 2011. Retrieved from http://ccsi.columbia.edu/files/2014/01/FDI_34.pdf.

- Chacar, A. S., Newburry, W., \& Vissa, B. (2010). Bringing institutions into performance persistence research: Exploring the impact of product, financial, and labor market institutions. Journal of International Business Studies, 41(7), 1119-1140.

- Chakrabarti, S., \& Ghosh, I. (2014). FDI in Africa: A comparison of the Indian and Chinese experience. Procedia-Social and Behavioral Sciences, 157, 340-352.

- Chang, S. J., \& Hong, J. (2000). Economic performance of group-affiliated companies in Korea: Intragroup resource sharing and internal business transactions. Academy of Management Journal, 43(3), 429-448.

- Conferência das Nações Unidas sobre Comércio e Desenvolvimento \{UNCTAD\} (2013b). Quem se beneficia com a liberalização do comércio em Angola? Uma perspectiva de gênero. UNCTAD/DITC/2013/3 (L. S. Magalhães, Trad.). Retrieved from http://unctad.org/en/PublicationChapters/ditc2013d3 _pr.pdf.

- Creswell, J. W. (2012). Qualitative inquiry and research design: Choosing among five approaches. Thousand Oaks, CA: Sage Publications.

- Cuervo-Cazurra, A., Inkpen, A., Musacchio, A., \& Ramaswamy, K. (2014). Governments as owners: Stateowned multinational companies. Journal of International Business Studies, 45(8), 919-942.

- Dunning, J. H. (2001). The eclectic (OLI) paradigm of international production: past, present and future. Journal of the Economics of Business, 8(2), 173-190.

- Dupasquier, C., \& Osakwe, P. N. (2006). Foreign direct investment in Africa: performance, challenges and responsibilities. Journal of Asian Economics, 17(2), 241260.

- Eisenhardt, K. M. (1989). Building theories from case study research. Academy of Management Review, 14(4), 532-550.

- Garcia, A. S., Kato, K., \& Fontes, C. (2014). A história contada pela caça ou pelo caçador? Reflexões sobre a inserção do Brasil na África. Tensões Mundiais, 10(1819), 145-171.

- Ghauri, P. (2004). Designing and conducting case studies in international business research. In $\mathrm{R}$. Marschan-Piekkari \& C. Welch (Eds.) Handbook of Qualitative Research Methods for International Business (pp. 109-124). Cheltenham, UK: Edward Elgar

- Guillén, M. F., \& García-Canal, E. (2009). The American model of the multinational firm and the "new" multinationals from emerging economies. The Academy of Management Perspectives, 23(2), 23-359.

- Iglesias, R. M., \& Costa, K. (2011). O investimento direto brasileiro na África. Textos CINDES, n. 27. Retrieved from

http://www.cindesbrasil.org/site/index.php?option=co $\mathrm{m}$ jdownloads\&ltemid $=62 \&$ view $=$ finish $\&$ cid $=616 \&$ cati $d=7$

- Johanson, J., \& Vahlne, J-E. (1977). The internationalization process of the firm: a model of knowledge development and increasing foreign market commitments. Journal of International Business Studies, 8(1), 23-32.

- Kaplinsky, R., \& Morris, M. (2009). Chinese FDI in SubSaharan Africa: engaging with large dragons. The European Journal of Development Research, 21(4), 551569.

- Khanna, T., \& Palepu, K. (1997). Why focused strategies may be wrong for emerging markets. Harvard Business Review, 75(4), 41-48.

- Khanna, T., \& Palepu, K. G. (2010). Winning in emerging markets: a road map for strategy and execution. Cambridge: Harvard Business Press.

- Kwok, C. C., \& Tadesse, S. (2006). The MNC as an agent of change for host-country institutions: FDI and corruption. Journal of International Business Studies, 37(6), 767-785.

- Luo, Y., \& Tung, R. L. (2007). International expansion of emerging market enterprises: a springboard perspective. Journal of International Business Studies, 38(4), 481-498.

- Narayanan, V. K., \& Fahey, L. (2005). The relevance of the institutional underpinnings of Porter's five forces framework to emerging economies: an epistemological analysis. Journal of Management Studies, 42(1), 207223.

- North, D. C. (1990). Institutions, institutional change, and economic performance. Cambridge: Cambridge University Press.

- Peng, M. W., Wang, D. Y. L., \& Jiang, Y. (2008). An institution-based view of international business strategy: a focus on emerging economies. Journal of International Business Studies, 39(5), 920-936.

- Ramamurti, R. (2012). What is really different about emerging market multinationals. Global Strategy Journal, 2(1), 41-47.

- Ramasamy, B., Yeung, M., \& Laforet, S. (2012). China's outward foreign direct investment: Location choice and firm ownership, Journal of World Business, 47(1), 17-25.

- Spink, P K (1999). Análise de documentos de domínio público. In MJ Spink (Ed.), Práticas discursivas e produção de sentidos no cotidiano: Aproximações teóricas e metodológicas (pp. 123-151). São Paulo, SP: Cortez Editora.

- United Nations Conference on Trade and Development (2011). World Investment Report 2011: Non-equity 
Modes of International Production and Development. Retrieved from http://unctad.org/en/publicationslibrary/wir2011_en.p df.

- United Nations Conference on Trade and Development (2013a). Global Investment Trends Monitor: The rise of BRICS FDI and Africa (Special Edition, Unedited version). Retrieved from http://unctad.org/en/PublicationsLibrary/webdiaeia20 13d6_en.pdf.

- Vilas-Bôas, J. C. (2011). A Atuação das empresas brasileiras na África no Governo Lula. (Monografia).
Instituto de Relações Internacionais, Universidade de Brasília, DF.

- Whalley, J., \& Weisbrod, A. (2012). The contribution of Chinese FDI to Africa's pre-crisis growth surge. Global Economy Journal, 12(4), DOI: https://doi.org/10.1515/1524-5861.1873.

- World Bank (2012). World Development Indicators Database. Retrieved from http://data.worldbank.org/country/brazil.

- Yin, R. K. (1994). Case study research: design and methods (Applied Social Research Methods Series, 5). London: Sage Publications.

\section{About the authors}

- Renato Souto Virches holds a Master in Business Administration from FEI, a MBA in Marketing from ESPM and two MBAs in Business Administration from FIA and FGV. He has 20 years of experience in consulting market investment and credit analysis and 10 years of teaching experience in the areas of market administration, business and innovation. He is currently CEO of Correct Data, a company of creation and development of credit information systems and services and he is a lecturer at Universidade Paulista.E-mail: rsvirches@uol.com.br

- Fernanda Ribeiro Cahen is Assistant professor of Management at Centro Universitário FEl. She was a post-doctoral fellow in International Business at Kelley School of Business at Indiana University in 20122013. She received her PhD in Business Administration in 2012 from University of Sao Paulo. E-mail: fribeiro@fei.edu.br 


\section{Como os vazios institucionais influenciam o investimento direto estrangeiro de multinacionais brasileiras em Angola}

\begin{tabular}{|c|c|}
\hline \multicolumn{2}{|c|}{$\begin{array}{l}\text { Renato Souto Virches }{ }^{A} \text {, Fernanda Ribeiro Cahen }{ }^{B} \\
\qquad{ }^{A, B} \text { Centro Universitário FEl, FEI/SP, Brasil }\end{array}$} \\
\hline DETALHES DO ARTIGO & RESUMO \\
\hline $\begin{array}{l}\text { Histórico do artigo: } \\
\text { Recebido em } 8 \text { de Março de } 2016 \\
\text { Aceito em } 4 \text { de Abril de } 2017 \\
\text { Disponível online in } 30 \text { April } 2017 \\
\text { Sistema de Revisão "Double Blind Review" } \\
\text { Editor científico } \\
\text { llan Avrichir }\end{array}$ & $\begin{array}{l}\text { Como os vazios institucionais influenciam as multinacionais de mercados } \\
\text { emergentes (MMEs) e o investimento direto estrangeiro (IDE) nos países em } \\
\text { desenvolvimento? Neste artigo, respondemos a esta questão com base em } \\
\text { uma abordagem de estudo de caso, examinando o IDE brasileiro em Angola } \\
\text { como nosso cenário analítico. Concentramo-nos nas instituições do país } \\
\text { anfitrião e nos seus vazios institucionais como fatores essenciais que atraem } \\
\text { o IDE da MMEs para os países em desenvolvimento. A pesquisa indica que as } \\
\text { empresas brasileiras preenchem grande parte desses vazios dentro dos } \\
\text { intermediários de mercado, muitas vezes criando um ponto de vantagem } \\
\text { competitiva, e também criando vantagens em relação ao IDEs de outras } \\
\text { economias que investem em Angola. Complementamos pesquisas recentes } \\
\text { sobre a influência das instituições do país anfitrião sobre o comportamento do } \\
\text { IDEs nos países em desenvolvimento, explicando como algumas MMEs podem } \\
\text { usar os vazios institucionais dos países em desenvolvimento como } \\
\text { oportunidades de mercado. Nossos resultados também trazem implicações } \\
\text { para os gestores de MMEs de outros mercados emergentes, fornecendo uma } \\
\text { melhor compreensão de como as multinacionais brasileiras expandem seus } \\
\text { negócios em países menos desenvolvidos, lidam com vazios institucionais e } \\
\text { gerenciam relacionamentos com instituições locais e estrangeiras no país } \\
\text { anfitrião. }\end{array}$ \\
\hline
\end{tabular}

C 2017 Internext | ESPM. Todos os direitos reservados.

To cite this article:

Virches, R. S. \& Cahen, F. R. (2017). How institutional voids influence Brazilian foreign direct investment in Angola. Internext - Revista Eletrônica de Negócios Internacionais, 12 (1), 33-47. DOI: 10.18568/19804865.12133-47

To access this article: $h t t p: / / d x . d o i . o r g / 10.18568 / 1980-4865.12133-47$ 